\title{
Study on the on-Farm Post-Natal Nutritional Status of Red Chittagong Cows in Selected Breeding Habitat of Satkania Upazila of Chittagong District of Bangladesh
}

\author{
Md. Asaduzzaman, ", Md. Ruhul Amin², Khan Shahidul Huque ${ }^{3}$ \\ ${ }^{1}$ Goat and Sheep Production Research Division, Bangladesh Livestock Research Institute, Dhaka, Bangladesh \\ ${ }^{2}$ Department of Animal Science, Bangladesh Agricultural University, Mymensingh, Bangladesh \\ ${ }^{3}$ Animal Production Research Division, Bangladesh Livestock Research Institute, Dhaka, Bangladesh
}

Email address:

shaju_blri@yahoo.com (Md. Asaduzzaman)

${ }^{*}$ Corresponding author

\section{To cite this article:}

Md. Asaduzzaman, Md. Ruhul Amin, Khan Shahidul Huque. Study on the on-Farm Post-Natal Nutritional Status of Red Chittagong Cows in Selected Breeding Habitat of Satkania Upazila of Chittagong District of Bangladesh. Animal and Veterinary Sciences.

Vol. 5, No. 4, 2017, pp. 57-62. doi: 10.11648/j.avs.20170504.12

Received: May 29, 2017; Accepted: June 15, 2017; Published: July 20, 2017

\begin{abstract}
The aim of the on farm feeding trials was to investigate the post-natal nutritional status of Red Chittagong (RC) cows. Farmers who had at least one post-natal RC cow were involved in this study. A total of ten farmers were randomly selected. The study was carried out in Satkania Upazila of Chittagong district of Bangladesh for a period of six months from July 2010 to December 2010. Immediately after calving ten post-natal RC cows from each of 10 farmers between 2 and 3 parities were selected in this experiment. The offered feeds and leftover feeds were weighted and recorded daily. The cows and calves were weighed individually at weekly interval by using portable digital weighing balance and recorded. The milking was done by hand milking. The milk yield of ten cows was measured immediately after milking and recorded regularly. The milk yield in morning and afternoon were considered as daily milk yield in $\mathrm{kg}$. The average total dry matter, metabolizable energy and crude protein intake were $3.53 \mathrm{~kg}, 27.56 \mathrm{MJ}$ and $281 \mathrm{~g}$ per cow per day, respectively, whereas, the average total DM, ME and $\mathrm{CP}$ requirements were $5.11 \mathrm{~kg}, 39.88 \mathrm{MJ}$ and $465 \mathrm{~g}$, per cow per day, respectively. The requirement was higher than the intake. The DM, ME and CP were deficit by $1.58 \mathrm{~kg}, 12.32 \mathrm{MJ}$ and $184 \mathrm{~g}$ per cow per day, respectively. The average daily live weight loss of cows was $12 \mathrm{~g}$. The average daily milk yield of RC cows was $2.45 \mathrm{~kg}$. The milk fat was $4.15 \mathrm{~g}$ per $100 \mathrm{~g}$ milk. The nutritional status of post-natal Red Chittagong cows was negative balance. Consequently, their production performances are affected. Therefore, the farmers feeding system is urgent to improve.
\end{abstract}

Keywords: Post-Natal Red Chittagong Cows, Feeds, Intake, Requirement, Nutritional Status, Weight, Milk

\section{Introduction}

Indigenous cattle of Bangladesh are most neglected in terms of low nutrition intake of total digestible nutrient and digestible crude protein. As a result, the balance of nutritional status is negative. The productivity of animals generally hampered by two main constraints of nutrition and health. The milk production is greatly affected by the level of nutrition. Concentrate feed increase the daily milk yield and total milk production per lactation [1]. Some sporadic onstation and on-farm studies in Bangladesh have shown that crossbred and local cows respond well to the supplementation of diet and as a result show increased voluntary feed intake, growth, milk production and fertility [2]. The energy supplemented feeding produces higher milk yield and better fertility rates and metabolic status over the first week of lactation in dairy cows as compared with nonsupplemented diet. Dietary deficiency of protein and energy are immediately reflected as decrease in total quantity of milk production [3]. The high levels of milk production are not possible without supply of energy and protein according to requirement [4]. However, Red Chittagong cattle is a potential dairy cattle variety of Bangladesh for its genetic 
merit, unique characteristics and milk yield and suitable for small-scale farmer [5]. This potential genetic resource is going to extinct improper feeding and management. The milk production performance of this variety is far below than specialized breed. But this variety produces more milk as compared to other indigenous cattle of Bangladesh. Therefore, conservation and improvement of this genetic resource is essential. There is no data on nutritional status of post-natal Red Chittagong cows in Bangladesh. Over the years, no study has been made for investigating the nutritional status of post-natal Red Chittagong cows under small-scale farm feeding condition. Therefore, it is necessary to find out the nutritional status of post-natal Red Chittagong cows with a view of improvement of post-natal Red Chittagong cows in Bangladesh. Thus, the present study was carried out under small-scale farm feeding condition of Satkania Upazila of Chittagong district of Bangladesh to know the feed and nutrient intake, requirement and nutritional balance of post-natal RC cows.

\section{Materials and Methods}

\subsection{Place and Duration of the Experiment}

The study was carried out in existing farming condition of Satkania Upazila of Chittagong district of Bangladesh. The duration of the study was six months from July 2010 to December 2010.

\subsection{Selection of Post-Natal Red Chittagong Cows}

Farmers who had at least one post-natal Red Chittagong (RC) cow were involved in this study. A total of ten farmers were randomly selected. Immediately after calving ten cows from each of 10 farmers between 2 and 3 parities were used in this experiment.

\subsection{Housing and Management Practices}

The RC cows were reared by the owners under their own feeding and management practices of farms condition. The RC cows were kept in separate conventional house. All animals were stall fed and followed stall feeding system.

\subsection{Feeding Roughages and Rice Bran}

The rice straw and naturally grown grasses were given twice daily, between 06:00 to 07:30 hours in the morning and between 15:30 to 16:30 hours in the afternoon. The rice straw supplied first followed by freshly cut naturally grown grasses. The rice bran as concentrate diet (polish and husk) was fed twice a day in the morning and afternoon before milking. The weight of roughages and rice bran were taken by using a top loading balance before supplying and recorded regularly. There was accessed of fresh drinking water, ad libitum to all the experimental animals.

\subsection{Estimation of Feed and Nutrient Intake}

The feed was weighted daily before supplying. The leftover feeds were also weighted and recorded on the following morning before offering morning feed. The daily feed intake was determined by subtracting the amount of leftover from the amount of feed given on the previous day. The metabolizable energy (ME) and crude protein (CP) was determined from the amount of dry matter (DM) fed in 24 hours. The ME and CP values were determined by multiplying respective $\mathrm{ME}$ and $\mathrm{CP}$ values of feeds.

\subsection{Calculation of CP Values of Intake Diet}

The calculation of $\mathrm{CP}$ values of intake diet based on ARC [6].

\subsection{Weight Determination of Post- Natal Red Chittagong Cows and Calves}

The post-natal experimental RC cows were weighed individually at weekly interval. The weight of cows was performed in morning before feeding. The calves were also weighed individually at weekly interval. The weigh was done by using the digital weighing balance and recorded from the start till the end of the trial. The weight of calves was taken before milking.

\subsection{Collection and Preparation of Feed Samples}

The rice straw, natural grasses and rice bran samples were collected from the study area for chemical analysis. The samples were cut into small pieces for determining DM content of fresh sample. At the same time, another portion of samples were dried in the sun and then grinded to pass through $40 \mathrm{~mm}$ mesh sieve. After grinding, the samples were kept in the polythene bags, labeled and stored. Dry matters of feeds were determined immediately after collection.

\subsection{Chemical Analysis of Feed Samples}

The fresh samples were dried at $55^{\circ} \mathrm{C}$ for $72 \mathrm{hrs}$ in a forced drying oven to determine DM content. The sun-dried samples were subjected to chemical analyses for organic matter (OM), crude protein (CP), crude fiber (CF), ether extract (EE), Ash and nitrogen free extract (NFE) following the procedure AOAC [7]. The metabolizable energy (ME) was determined by using the in-vitro gas production techniques [8]. All the samples were analyzed in duplicate and mean values were recorded.

\subsection{Measurement and Recording of Milk Yield}

The experimental cows were milked twice a day, between 07:30 to 09:00 hours in morning and between 15:30 to $16: 30$ hours in afternoon. The milking was done by hand milking. The milk yield was measured immediately after milking and recorded regularly. The milk yield in morning and afternoon were considered as daily milk yield in $\mathrm{kg}$.

\subsection{Estimation of Fat Corrected Milk}

The fat corrected milk yield (FCM) was calculated by using the following formula: 


$$
\mathrm{FCM}=\mathrm{M}(0.4+0.15 \mathrm{X} \mathrm{F})
$$

Where, $\mathrm{M}=$ Milk yield and $\mathrm{F}=$ Fat percent

\subsection{Collection and Chemical Analysis of Milk}

The milk samples were collected from individual cows in a plastic bottle $(100 \mathrm{ml})$ with the identifying marks for chemical analysis. Analysis was done for fat, protein, solids-not-fat (SNF), total solids (TS) and ash contents of milk with the help of a milk analyzer machine Lacto Star (c) 2005, Funke Gerber, Firmware Rev: 3.24c, \# 3510-080203. All the samples were analyzed in duplicate and mean values were recorded.

\subsection{Nutrient Requirements of Post-Natal Red Chittagong Cows}

The daily dry matter (DM), metabolizable energy (ME) and crude protein $(\mathrm{CP})$ requirements of post-natal RC cows were calculated based on ARC [6].

\subsection{Data Collection and Statistical Analysis}

The data on daily feed intake, weekly live weight of cows and calves, daily milk yield, post partum heat period and conception rate were recorded and collected for statistical analysis. The data were analyzed by using the Microsoft Office Excel Worksheet 2007. Mean values and standard error difference were calculated.

\section{Results and Discussion}

\subsection{Chemical Composition of Feeds}

The nutrient composition of feeds fed to the post-natal Red Chittagong cows are presented in Table 1. The chemical composition of feeds gives very rough idea about its characteristics and nutritive values. It is the first step which a chemist has to take in order to determine the nutritive value. These measurement unable to indicate the form of availability to nutrients but provides information on potential nutrient content. In the present study, farmers offered rice straw, natural grasses and rice bran (Husk plus polish) as a concentrate diet to their post-natal RC cows. The DM content of rice straw was lower than the findings of $[9,10]$. The OM content of the same rice straw was higher than the values reported by Nader and Robinson [11]. The CP content of rice straw was lower than the findings of $[8,12,5,13]$, respectively. The $\mathrm{CF}$ content of rice straw was higher than the findings [13]. The EE, Ash and NFE contents of rice straw were almost similar to the observation of [13]. The ME content of rice straw was lower than the findings of $[8,12]$. The variation of chemical composition of rice straw may be due to ambient temperature, day length, humidity, rainfall and moisture content of soil, season and location. The DM content of natural grasses in the present study was lower than the values reported by Ranjhan and Katiyar [14], Alam [15], Mahatab et al. [16], Sarker [17], Rahman et al. [18] and Alam et al. [19], respectively. The OM and CP content of natural grasses was found similar with the findings of [19]. The CP content of the same natural grasses was less similar to that reported by [17]. The CF content of natural grasses was almost similar with the findings of [19]. The EE, Ash and NFE content of natural grasses were more or less similar with the findings of [19]. The DM content of rice bran was similar with the findings of [13]. The OM content of same rice bran was higher than the findings of Islam [20]. The CP content of rice bran was lower than the findings of [12]. The variation of $\mathrm{CP}$ content of rice bran may be due to nutrient availability in soil, $\mathrm{N}$ fertilizer application to the soil and husk content. The CF, Ash and EE content of rice bran was more or less similar to the values reported by [20]. The ME content of rice bran was found same natural grasses were almost similar with the findings of [11]. The variation of $\mathrm{DM}, \mathrm{ME}$ and $\mathrm{CP}$ content of natural grasses may be due to water content of natural grasses, varieties, stage of maturity, part of the plant, rapid growth of grasses, location and season.

Table 1. Chemical composition of feeds fed to the post-natal Red Chittagong cows.

\begin{tabular}{|c|c|c|c|c|c|c|c|c|}
\hline \multirow{2}{*}{ Name of feed } & \multirow{2}{*}{ DM (g/100g sample) } & \multicolumn{6}{|c|}{ Chemical composition (g/100g DM) } & \multirow{2}{*}{ ME (MJ/kg DM) } \\
\hline & & OM & $\mathbf{C P}$ & $\mathbf{C F}$ & $\mathbf{E E}$ & Ash & NFE & \\
\hline Rice straw & 87.50 & 86.80 & 3.50 & 51.23 & 1.92 & 13.13 & 45.70 & 5.38 \\
\hline Natural grasses & 16.00 & 91.07 & 11.67 & 37.50 & 1.60 & 8.90 & 54.60 & 7.29 \\
\hline Rice bran & 88.71 & 93.33 & 6.90 & 36.84 & 3.47 & 6.67 & 34.80 & 10.73 \\
\hline
\end{tabular}

$\mathrm{DM}=$ Dry matter; $\mathrm{OM}=$ Organic matter $\mathrm{CP}=$ Crude protein $\mathrm{CF}=$ Crude fiber; $\mathrm{EE}=$ Ether extract; $\mathrm{A}=\mathrm{Ash} ; \mathrm{NFE}=$ Nitrogen free extract; $\mathrm{ME}=$ metabolizable energy; $\mathrm{MJ}=$ Mega joule.

\subsection{Feed and Nutrient Intake of Post-Natal Red Chittagong Cows}

The feed and nutrient intake of post-natal RC cows is depicted in Table 2. The average live weight $(\mathrm{kg})$ and metabolic live weight $\left(\mathrm{kgW}^{0.75}\right)$ of post-natal RC cows was 175.47 and 48.21, respectively (Table 4). The total DM, ME and CP intake were $3.53 \mathrm{~kg}, 27.56 \mathrm{MJ}$ and $281 \mathrm{~g}$, per day, respectively. The $\mathrm{CP}$ value of intake diet was $79.60 \mathrm{~g}$, per $\mathrm{kg}$ DM, respectively. Yasmin [21] reported that total DM intake of RC cows ranged from 5.60 to $7.88 \mathrm{~kg}$ per day, which was higher than the findings of the present experiment. The daily total DM intake on the basis of metabolic live weight $(\mathrm{kg}$ $\mathrm{W}^{0.75}$ ) was lower than the findings of Islam [20], who

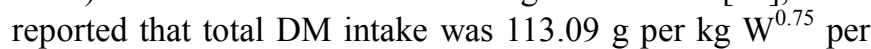
day unsupplemented (US) based diet. The total DM intake $\mathrm{kg}$ per $100 \mathrm{~kg}$ live weight of post-natal RC cows in the present experiment was lower than the findings of Sharma et al. [22], who reported that DM intake is 2.6 percent of live weight. The variation of feed and nutrient intake of post-natal RC 
cows in the present experiment may be due to plane way supply feeds, availability of feeds, inadequate and imbalance feeding.

\subsection{Present Nutritional Status, Requirement and Nutrient Balance of Post-Natal Red Chittagong (RC) Cows}

The nutritional status of a cow depended on feed intake and supply, feed quality, management practice and season. The nutritional status, requirement and nutrient balance of post-natal RC cows are presented in Table 3. The total DM, $\mathrm{ME}$ and CP requirement of post-natal RC cows' were $5.11 \mathrm{~kg}$, $39.88 \mathrm{MJ}$ and $465 \mathrm{~g}$, per day, respectively. The M/D and CP values of requirement diet were $11.30 \mathrm{MJ}$ and $131.73 \mathrm{~g}$, per $\mathrm{kg} \mathrm{DM}$, respectively. The DM, ME and CP intake were deficit by $1.58 \mathrm{~kg}, 12.32 \mathrm{MJ}$ and $184 \mathrm{~g}$, respectively, than the requirement. As a result, the nutritional status was negative.

In the present experiment, the DM requirement of postnatal experimental RC cows was lower than the ARC [6] standard (3.5 kg per cow per day). The findings of the present experiment were also supported by the findings of Ahmed [10], who reported that the DM requirement was $1.63 \mathrm{~kg}$ higher than the intake. The ME requirement of post-natal RC cows in the present study was lower than ARC [6] standard. According to ARC [6], the ME requirement of lactating "standard" cows is $42.90 \mathrm{MJ}$ per cow per day. Ahmed [10] reported that the daily ME requirement was $0.20 \mathrm{MJ}$ higher than the intake. The findings of the present experiment are in good agreement with the findings of Ahmed [10]. The CP requirement of the present study was lower than the ARC [6] standard. According to ARC [6], the $\mathrm{CP}$ requirement of lactating "standard" cows is $535 \mathrm{~g}$ per day. The variation of $\mathrm{DM}, \mathrm{ME}$ and $\mathrm{CP}$ requirement of post-natal RC cows might be due to body size, breed and supply of feeds. The DM, ME and $\mathrm{CP}$ balance of post-natal RC cows was deficit. The reason of deficit balance may be due to inadequate supply of rice straw this is because of very small cultivated land available per household as Chittagong is a hilly area. Moreover, $\mathrm{CP}$ and ME content of rice straw is below than the threshold value of crude protein $(\mathrm{CP}>7-8 \%)$ and energy (ME $>9-10 \mathrm{MJ}$ per $\mathrm{kg} \mathrm{DM}$ ). Although the supply of natural grasses was higher but it could not fulfill the DM requirements this is because of mostly aquatic plants. That also content lower threshold values of energy (ME $>9-10 \mathrm{MJ}$ per kg DM).

Table 2. Feed and nutrient intake of post-natal Red Chittagong cows.

\begin{tabular}{|c|c|c|}
\hline Parameters & Mean $(n=10)$ & \pm SED \\
\hline DM intake of rice straw (kg/day) & 0.98 & 0.04 \\
\hline DM intake of natural grasses ( $\mathrm{kg} /$ day) & 1.47 & 0.03 \\
\hline DM intake of rice bran (kg/day) & 1.08 & 0.05 \\
\hline Total DM intake (kg/day) & 3.53 & 0.01 \\
\hline Total DM intake ( $\mathrm{kg} / 100 \mathrm{~kg}$ live weight) & 2.01 & 0.01 \\
\hline Total ME intake (MJ/day) & 27.56 & 0.17 \\
\hline Total CP intake (g/day) & 281 & 4.08 \\
\hline Total DM intake (g/ kg W ${ }^{0.75} /$ day) & 73 & 0.49 \\
\hline Total ME intake (MJ/ $\mathrm{kg} \mathrm{W}^{0.75} /$ day) & 0.57 & 0.03 \\
\hline Total CP intake ( $\mathrm{g} / \mathrm{kg} \mathrm{W}^{0.75} /$ day) & 5.83 & 0.09 \\
\hline $\mathrm{CP}$ values of intake diet (g/kg DM) & 79.60 & 0.64 \\
\hline
\end{tabular}

$\mathrm{n}=$ Number of cows; $\mathrm{SED}=$ Standard error difference; $\mathrm{DM}=$ Dry matter; $\mathrm{ME}=$ Metabolizable energy; $\mathrm{M} / \mathrm{D}=$ Energy concentration of diet dry matter; $\mathrm{CP}=$ Crude protein.

Table 3. Present nutritional status, requirement and nutrient balance of post-natal Red Chittagong cows.

\begin{tabular}{llll}
\hline Parameters & Nutrient intake of FD \pm SED & Nutrient requirement) \pm SED & Nutrient balance \\
\hline Total DM (kg/day) & $3.53 \pm 0.01$ & $5.11 \pm 0.59$ \\
Total DM (kg/100kg live weight) & $2.01 \pm 0.01$ & $2.91 \pm 0.37$ \\
Total DM (g/kg W ${ }^{0.75} /$ day) & $73 \pm 0.49$ & $106 \pm 0.01$ & -1.58 \\
Total ME (MJ/day) & $27.56 \pm 0.17$ & $39.88 \pm 4.47$ \\
Total ME $\left(\mathrm{MJ} / \mathrm{kg} \mathrm{W}^{0.75} /\right.$ day) & $0.57 \pm 0.03$ & $0.83 \pm 0.10$ & -0.90 \\
Total CP $(\mathrm{g} /$ day) & $281 \pm 4.08$ & $465 \pm 67.62$ \\
Total CP $\left(\mathrm{g} / \mathrm{kg} \mathrm{W}{ }^{0.75} /\right.$ day) & $5.83 \pm 0.09$ & $9.65 \pm 1.49$ \\
CP values $(\mathrm{g} / \mathrm{kg} \mathrm{DM})$ & $79.60 \pm 0.64$ & $131.73 \pm 1.82$ \\
\hline
\end{tabular}

$\mathrm{FD}=$ Farmers diet; $\mathrm{LW}=$ Live weight; $\mathrm{SED}=$ Standard error difference; $\mathrm{DM}=$ Dry matter; $\mathrm{ME}=$ Metabolizable energy; $\mathrm{M} / \mathrm{D}=\mathrm{Energy}$ concentration of diet dry matter; $\mathrm{CP}=$ Crude protein.

\subsection{Productive Performances of Post-Natal Red Chittagong (RC) Cows}

\subsubsection{Live Weight Changes of Cows}

The live weight changes of post-natal RC cows are shown in Table 4. The initial live weight of RC cows was $182.30 \mathrm{~kg}$ and the final live weight after six months of experiment was $180.15 \mathrm{~kg}$. After six months of experiment, the total live weight loss of cows was $2.15 \mathrm{~kg}$. Thus, the daily live weight loss was $12 \mathrm{~g}$. The findings of present experiment are in disagreement with the findings of Yasmin [21] and Debnath et al. [23]. Islam [20] reported that the daily live weight gain of lactating Red Chittagong cow's on-station and on-farmer conditions was 80 and $50 \mathrm{~g}$, respectively. The reasons behind the live weight loss might be due to the feed and milk production.

Table 4. Live weight changes of cows, milk production and milk composition, growth performances of calves and reproductive performances of post-natal Red Chittagong cows.

\begin{tabular}{|c|c|c|}
\hline Parameters & Mean $(n=10)$ & \pm SED \\
\hline Average initial live weight $(\mathrm{kg})$ & 182.30 & 10.29 \\
\hline Average final live weight $(\mathrm{kg})$ & 180.15 & 10.22 \\
\hline $\begin{array}{l}\text { Six experimental period average live weight } \\
(\mathrm{kg})\end{array}$ & 175.47 & 0.54 \\
\hline $\begin{array}{l}\text { Six experimental period average metabolic } \\
\text { live weight }\left(\mathrm{kgW}^{0.75}\right)\end{array}$ & 48.21 & 0.11 \\
\hline Total live weight loss (kg) & -2.15 & 0.31 \\
\hline Daily live weight loss of cows ( $g$ ) & -12 & 1.75 \\
\hline Lactation length (days) & 180 & - \\
\hline Milk yield (kg/day) & 2.45 & 0.11 \\
\hline
\end{tabular}




\begin{tabular}{lll}
\hline Parameters & Mean $(\mathbf{n}=\mathbf{1 0})$ & \pm SED \\
\hline Fat corrected milk (kg/day) & 2.50 & 0.10 \\
Fat & 4.15 & 0.01 \\
Protein & 3.81 & 0.03 \\
Solids not fat & 9.09 & 0.11 \\
Total solids & 13.24 & 0.12 \\
Ash & 0.71 & 0.02 \\
Initial live weight $(\mathrm{kg})$ of calves & 10.95 & 0.24 \\
Final live weight $(\mathrm{kg})$ of calves & 44.25 & 0.57 \\
Total live weight gain (kg) of calves & 33.30 & 2.11 \\
Daily live weight gain (g) of calves & 185 & 11.77 \\
Post-partum heat period (days) & 106 & 1.80 \\
Service per conception (no.) & 1.70 & 0.21 \\
\hline
\end{tabular}

$\mathrm{n}=$ Number of cows; $\mathrm{SED}=$ Standard error difference.

\subsubsection{Milk Production and Composition of Milk}

The milk production performances of post-natal Red Chittagong cows and composition of milk are presented in Table 4 . The average daily milk yield of RC cows in the present study was $2.45 \mathrm{~kg}$. The live weight gain is negative but milk production is high. The reasons behind the energy and protein of body stores are mobilized to support the high milk production. As a result live weight gain is negative. Thus, the fat corrected milk (FCM) yield was $2.51 \mathrm{~kg}$ per day. The findings of the present experiment were higher than the findings of Akhter et al. [24]. They are reported that the milk yield of indigenous cows is $1.84 \mathrm{~kg}$ per day. There are many factors influencing to milk production performances of cows like breed, lactation length, environment, nutrition and interaction between nutrition and environment. In the present experiment, the lactation length of RC cows was 180 days. However, Khan et al. [2] reported the lactation period of Red Chittagong cattle in farm and rural conditions were $222.85 \pm$ 16.03 and $214.7 \pm 21.68$ days, respectively.

The milk fat, protein, solids not fat and total solids was $4.15,3.81,9.09$ and 13.24 , g per $100 \mathrm{~g}$ milk, respectively. The milk composition is significantly varied by numerous factors of species, breed, nutrient, climate, stage of lactation etc of which nutrient is an important. Milk constituents such as milk fat, proteins, lactose and ash are derived from the absorbed dietary nutrients of the cows. The production and composition of milk varies with the uptake of nutrients by the mammary gland and this is influenced by mammary blood flow and utilization of nutrients by mammary gland [25]. However, in the present experiment, it was found that milk fat, protein, solids not fat and total solids contents of RC cow's milk were higher than the findings of Mutukumira et al. [26]. They are reported that milk protein, milk fat, total solids and solids-not-fat was 3.19, 3.52, 11.76 and 8.25 percent, respectively.

\subsubsection{Growth Performances of Red Chittagong (RC) Calves}

The growth performance of RC calves is shown in Table 4. The average initial live weight i.e. the birth weight of RC calves was $10.95 \mathrm{~kg}$. The final weight after six months of experiment was $44.25 \mathrm{~kg}$. Thus, the growth of total live weight and growth rate of RC calves was $33.30 \mathrm{~kg}$ and $185 \mathrm{~g}$, per day, respectively. The findings of the present study was very much close with the findings of Habib et al. [27] and
Debnath et al. [23]. Habib et al. [27] reported that the growth rate of $\mathrm{RC}$ calves was $190 \mathrm{~g}$ per day. However, the performance of calves in terms of growth is affected by birth weight, parity, milk production of cows and management practices.

\subsubsection{Reproductive Performances of Post-Natal Red Chittagong Cows}

The reproductive performances of post-natal RC cows are shown in Table 4. The post partum heat period (PPHP) and service per conception (no.) was 106 days and 1.70. The post-partum heat is depended on nutritional status of cows. If the post-partum heat period is short, cows are impregnated earlier and calves are born early. However, the total productive performance of cows is affected by dam PPHP. In the present experiment, it was found that the average PPHP of post-natal RC cows was lower than the findings of Islam [20], who reported that the PPHP of indigenous cow's is 180 days. The service per conception is an important indicator of fertility as well as the reproductive efficiency of cows. It is affected by nutrition and health status of cows. The average service per conception (no.) of post-natal experimental RC cows was similar with the findings of Sultana [28] who reported that the service per conception (no.) of local cows was 1.78 .

\section{Conclusion}

The results of the present experiment show that intake was lower than the requirement. Therefore, it is recommended that the small-scale farm feeding needs to be improved.

\section{References}

[1] M. N. Haque, S. A. Aziz, S. S. Chanda, M. I. Hossain and M. A. Baset, A study of the milking and reproductive performances of indigenous cattle at urban area of Bangladesh. Pakistan Journal of Biological Science. 2002; 5: $97-100$.

[2] M. K. I. Khan, K. S. Huque, A. G. Miah and M. J. Khatun, Study on the performances of Red Chittagong cows under different production system. Pakistan Journal of Biological Science. 2000; 3: 318 - 319.

[3] L. H. Meyer, In: Food Chemistry. An East- West Edition: Affiliated East-West Press Pvt. Ltd. New Delhi, India. 1973. pp. 385.

[4] P. C. Garnsworthy and D. J. A. Cole, Recent Advances in Animal Nutrition. Nottingham University Press, Nottingham, United Kingdom. 1993.

[5] M. S. A. Bhuiyan, A. K. F. H. Bhuiyan, D. H. Yoon, J. T. Jeon, C. S. Park and J. H. Lee, Mitochondrial DNA diversity and origin of Red Chittagong cattle. Asian- Australasian Journal of Animal Science. 2007; 20: 1478 - 1484.

[6] ARC (Agricultural Research Council). The Nutrient Requirements of Ruminant Livestock. CAB International, Wallingford, United Kingdom. 1995. pp. 73 -310. 
[7] AOAC (Association of Official Agricultural Chemists). Official Methods of Analysis. $17^{\text {th }}$ edition. AOAC, Washington D. C. 2003.

[8] K. H. L. Menke, L. Raab, A. Salewaskki, H. Steingass, D. Fritz and W. Schnerider, The estimation of digestibility and metabolizable energy content of ruminant feedstuffs from the gas production when they are incubated with rumen liquor in vitro. Journal of Agricultural Science. 1979; 93: 217 - 222.

[9] B. V. Chinh and L. Viet Ly, Protein of agro-byproducts as feed resources for buffaloes in Vietnam. In: Proceedings of Buffalo Workshop. 2001. 17-18 December, 2001. http://www.mekarn.org/procbuf/chin.htm

[10] T. U. Ahmed, Studies on nutritional status of dairy cows of Bangladesh and improvement of their productive and reproductive performance in Baghabarighat area through nutritional manipulation, PhD Thesis, Department of Animal Nutrition, Bangladesh Agricultural University, Mymensingh. 2006.

[11] G. A. Nader and P. H. Robinson, Effects of maceration of rice straw on voluntary intake and performance of growing beef cattle fed rice straw-based rations. Animal Feed Science and Technology. 2008; 146: 74 - 86.

[12] D. Kiran and U. Krishnamoorthy, Rumen fermentation and microbial biomass synthesis indices of tropical feedstuffs determination by the in vitro gas production technique. Animal Feed Science and Technology. 2007; 134: 170 - 179.

[13] D. Floulkes, Rice straw as a livestock feed. Agnote. 1998; 22: $273-275$.

[14] S. K. Ranjhan and R. C. Katiyar, Chemical Composition and nutrition value of Makra (Daetylocteniom egiptiumlin) and indigenous monsoon grass. Indian Journal of Dairy Science. 1969; 22: 92 - 94.

[15] M. R. Alam, Potential use legume tree leaves as forage in Bangladesh. In: Winrock International (JN Daneol and JM Roshetok), Nitrogen fixing trees for fodder production. United State of America. 1998. pp. 205 - 211.

[16] S. N. Mahatab, A. Ali and A. H. M. Asaduzzaman, Average chemical composition and nutritive value of livestock feeds. Animal Nutrition Section, Livestock Research Section, Mohakhali, Dhaka. 1987; 12: 4 - 13.

[17] M. A. Sarker, Economic Analysis of Dairy Cattle Enterprise and its pattern of contribution to Farm income in a selective area of Bangladesh, MS Thesis, Department of Agricultural Economics, Bangladesh Agricultural University, Mymensingh. 1995.

[18] M. M. Rahman, S. Akhtar and M. M. Hossaain, The availability of livestock feeds and feeding practices followed by the farmers of some areas of Mymensingh District. Bangladesh Journal of Animal Science. 1998; 27: 119 - 126.

[19] M. Alam, A. K. F. H. Bhuiyan, A. Ali and A. Mamun, Genetic analysis of birth weight and milk production of Red Chittagong cattle of Bangladesh. Bangladesh Journal of Animal Science. 2007; 36: 24 - 32.

[20] S. S. Islam, Development of feeding system for improving productive performance of Red Chittagong cattle of Bangladesh, PhD Thesis, Department of Animal Nutrition, Bangladesh Agricultural University, Mymensingh. 2010.

[21] M. F. Yasmin, Effect of supplementing concentrate on intake, digestibility, milk yield and composition of Red Chittagong cows fed Urea Molasses straw based diet, MS Thesis, Department of Animal Nutrition, Bangladesh Agricultural University, Mymensingh. 2006.

[22] K. Sharma, N. Dutta and U. Naulia, An on-farm appraisal of feeding urea - treated straw to buffaloes during late pregnancy and lactation in a mixed farming system. Livestock Research for Rural Development. 2004; 16: 1 - 10.

[23] G. K. Debnath, A. K. M. H. Kober, T. Chanda, M. A. Hoque and M. A. Halim, Effect of supplementary concentrate feeding on milk production, quality and body weight changes of Red Chittagong cows and their calves under village management condition. Pakistan Journal of Biological Sciences. 2003; 6: $945-947$.

[24] S. Akhter, K. S. Huque, M. A. Jalil and M. R. G. Islam, Conservation, selection and improvement of Red Chittagong cattle selective breeding, feeding and management. Proc. Annual Res. Rev. Workshop, 10-11 June, 2004, Bangladesh Livestock Research Institite, Savar, Dhaka. 2004.

[25] A. Bhuiyan, M. A. Akbar and M. E. Hossain, Nutritive value of damp rice straw and its feeding effect on aflatoxin transmission into cow's milk. Pakistan Journal of Nutrition. 2003; $2: 153-158$.

[26] A. N. Mutukumira, S. B. Feresu, J. A. Narbhus and R. K. Abrahamsen, Chemical and Microbiological quality of raw milk produced by smallholder farmers in Zimbabwe. Journal of Food Production. 1996; 59: 984 - 987.

[27] M. A. Habib, A. K. F. H. Bhuiyan, M. S. A. Bhuiyan and A. A. Khan, Performance of Red Chittagong Cattle in Bangladesh Agricultural University Dairy Farm. Bangladesh Journal of Animal Science. 2003; 32: 101 - 108.

[28] R. Sultana, Quantitative analysis of reproductive performance of pure breed and their crosses in the Savar Dairy Farm, MS Thesis, Department of Animal Breeding and Genetics, Bangladesh Agricultural University, Mymensingh. 1995. 